\title{
Effects of Heat Treatment on Surface Recrystallization and Stress Rupture Properties of a Fourth-Generation Single-Crystal Superalloy after Grit Blasting
}

\author{
Zhen-Xue Shi ${ }^{1} \cdot$ Shi-Zhong Liu ${ }^{1} \cdot$ Xiao-Guang Wang ${ }^{1} \cdot J^{\prime a-R o n g ~}$ Li $^{1}$
}

Received: 13 November 2016/Revised: 11 December 2016/Published online: 16 February 2017

(C) The Chinese Society for Metals and Springer-Verlag Berlin Heidelberg 2017

\begin{abstract}
The specimens of a fourth-generation single-crystal superalloy were grit-blasted and heat-treated in vacuum at $1100,1150,1200,1250$ and $1300{ }^{\circ} \mathrm{C}$ for $4 \mathrm{~h}$, respectively. Then, the microstructure and the stress rupture properties of the recrystallized alloy were investigated at $1150{ }^{\circ} \mathrm{C} / 120 \mathrm{MPa}$. The results showed that a cellular recrystallization occurred in the surface layer after heating at 1100,1150 and $1200{ }^{\circ} \mathrm{C}$ for $4 \mathrm{~h}$. An equiaxed recrystallization formed as the specimen was heat-treated at $1300{ }^{\circ} \mathrm{C}$ for $4 \mathrm{~h}$, while a mixed recrystallization occurred in the specimen heat-treated at $1250{ }^{\circ} \mathrm{C}$ for $4 \mathrm{~h}$. The recrystallized depth clearly increased with a rise of the heat treatment temperature. The stress rupture life continuously decreased with a rise of the heat treatment temperature up to $1250{ }^{\circ} \mathrm{C}$. Although the overall stress rupture life reduced to different degrees, the stress rupture life of specimen after heat treatment at $1300{ }^{\circ} \mathrm{C}$ was relatively high and intermediate between those of specimens treated at 1150 and $1200{ }^{\circ} \mathrm{C}$. The fact that the stress rupture life reduced to different degrees after heat treatment can be attributed to the recrystallization of the surface layer and to the microstructure evolution of the interior of the specimen. The small $\gamma^{\prime}$ phase precipitated again after heat treatment at $1300{ }^{\circ} \mathrm{C}$ for $4 \mathrm{~h}$. So, the stress rupture life was relatively longer than that after heat treatment at 1200 or $1250{ }^{\circ} \mathrm{C}$ although the equiaxed recrystallization formed in the surface layer.
\end{abstract}

KEY WORDS: Single-crystal superalloy; Heat treatment; Recrystallization; Stress rupture properties

\section{Introduction}

Single-crystal nickel-based superalloys are mainly used as turbine blades in advanced gas turbine engines [1,2]. Their outstanding performance at high temperature mainly can be attributed to an almost complete elimination of all the grain boundaries [3]. As plastic deformation is introduced into the single-crystal superalloy during the manufacturing processes such as casting, grinding, grit blasting or shot

Available online at http://link.springer.com/journal/40195

Zhen-Xue Shi

shizhenxue@126.com

1 Science and Technology on Advanced High Temperature Structural Materials Laboratory, Beijing Institute of Aeronautical Materials, Beijing 100095, China peening, recrystallization will occur at the surface of the alloy during the subsequent heat treatment or service at high temperatures [4-7]. The tendency of surface recrystallization will enhance with the increase in the annealing temperature and of the deformation extent [8-11]. Singlecrystal superalloys contain small amounts of grain boundary strengthening elements. The mechanical properties of single-crystal components are dramatically affected by recrystallized grains because they may introduce disadvantageous orientations and high-angle grain boundaries $[12,13]$. The recrystallization phenomena of single-crystal superalloys have been studied extensively in the past several decades. The effects of recrystallization on the stress rupture properties and fatigue properties of single-crystal superalloys have been reported [14-16]. However, the information concerning the surface recrystallization of the fourth-generation single-crystal superalloys in the open 
literature is very scarce. The present work investigated the effect of the heat treatment at different temperatures on the surface recrystallization behavior and stress rupture properties of the new generation single-crystal superalloys after grit blasting, with the aim of promoting their development and application in future.

\section{Experimental}

A $\mathrm{Ni}-\mathrm{Cr}-\mathrm{Co}-\mathrm{Mo}-\mathrm{W}-\mathrm{Ta}-\mathrm{Nb}-\mathrm{Re}-\mathrm{Ru}-\mathrm{Al}$ single-crystal alloy with [001] orientation was cast by means of crystal selection method in a directionally solidification furnace with a temperature gradient of $80^{\circ} \mathrm{C} / \mathrm{cm}$. The nominal chemical composition of the alloy is shown in Table 1 . The crystal orientation of the specimens was determined with Laue X-ray back-reflection method, and the crystal orientation deviations of the specimens were maintained within $10^{\circ}$ from the [001] orientation. The single-crystal specimens received a standard heat treatment comprising a solution treatment $\left(1340{ }^{\circ} \mathrm{C} / 6 \mathrm{~h}, \mathrm{AC}\right)$ and a two-step aging treatment $\left(1120^{\circ} \mathrm{C} / 4 \mathrm{~h}, \mathrm{AC}+870{ }^{\circ} \mathrm{C} / 32 \mathrm{~h}, \mathrm{AC}\right)$. Small columns $(\Phi 10 \mathrm{~mm} \times 10 \mathrm{~mm})$ for microstructure observation and standard cylindrical specimens for stress rupture properties tests were machined after heat treatment. All the specimens were grit-blasted at a pressure of $0.25 \mathrm{MPa}$ for $30 \mathrm{~s}$, respectively, using $\mathrm{SiO}_{2}$ spheres with a radius of $120 \mu \mathrm{m}$. All the grit-blasted pieces were sealed in a vacuum quartz tube and then subjected to heat treatment at $1100,1150,1200,1250$ and $1300{ }^{\circ} \mathrm{C}$ for $4 \mathrm{~h}$, respectively. All the heat treatments were followed by air cooling. The stress rupture property tests were conducted at $1150{ }^{\circ} \mathrm{C} /$ $120 \mathrm{MPa}$ in air using a testing machine with furnace attachment. The samples were etched with $5 \mathrm{~g}$ $\begin{array}{llll}\mathrm{CuSO}_{4}+25 \mathrm{~mL} & \mathrm{HCl}+20 \mathrm{~mL} & \mathrm{H}_{2} \mathrm{O}+5 \mathrm{~mL} & \mathrm{H}_{2} \mathrm{SO}_{4}\end{array}$ which dissolves the $\gamma^{\prime}$ phase. The microstructures after the different heat treatments were examined by a scanning electron microscope.

\section{Results}

\subsection{Surface Recrystallization}

Figure 1 shows the surface microstructure of the alloy after grit blasting. The $\gamma^{\prime}$ phase in the surface was no longer

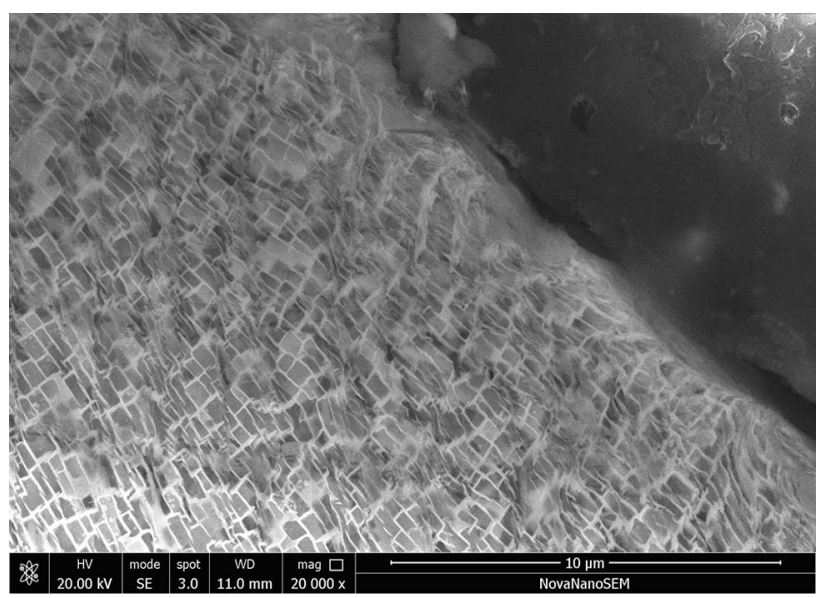

Fig. 1 Surface microstructure of the grit-blasted specimen without heat treatment

cubic in shape and was severely distorted because it was cold-worked by grit blasting. The average depth of the cold-worked zone was of approximately $10 \mu \mathrm{m}$.

Figures $2 \mathrm{a}-\mathrm{h}$ illustrate the surface microstructure evolution of the grit-blasted samples after heat treatment at different temperatures, respectively. The microstructure of the grit-blasted alloy after heating at $1100{ }^{\circ} \mathrm{C}$ for $4 \mathrm{~h}$ is shown in Fig. 2a. A cellular recrystallization occurred in the surface layer. The recrystallization cell is small and its number is less. A similar structure was observed in the gritblasted specimen heat-treated at $1150{ }^{\circ} \mathrm{C}$ for $4 \mathrm{~h}$, as shown in Fig. 2b, but its recrystallization cell was far larger and its number is more. The direction of the cellular $\gamma^{\prime}$ phase is approximately perpendicular to the interface between the recrystallization and the original zone. A perfect cellular recrystallization can be seen in the grit-blasted specimen heat-treated at $1200{ }^{\circ} \mathrm{C}$ for $4 \mathrm{~h}$ (Fig. 2c). The shape of the $\gamma^{\prime}$ phase in the cellular recrystallization tends to be equiaxed or cubic near the specimen surface and lamellar at the interface between the recrystallization and the original zone.

The microstructure of the grit-blasted alloy after heating at $1250{ }^{\circ} \mathrm{C}$ for $4 \mathrm{~h}$ is shown in Fig. $2 \mathrm{~d}$, e. An equiaxed recrystallization formed near the surface, while a cellular recrystallization was located between the equiaxed recrystallization and the original zone. The shape of $\gamma^{\prime}$ phase in the cellular recrystallization changed from lamellar to coarse and equiaxed. The cellular recrystallization zone consisted of coarse $\gamma^{\prime}$ phase and fine $\gamma+\gamma^{\prime}$.

Table 1 Nominal chemical compositions of the experimental alloy (mass fraction, \%)

\begin{tabular}{lllllllllllll}
\hline Element & $\mathrm{Cr}$ & $\mathrm{Co}$ & $\mathrm{Mo}$ & $\mathrm{W}$ & $\mathrm{Ta}$ & $\mathrm{Re}$ & $\mathrm{Ru}$ & $\mathrm{Nb}$ & $\mathrm{Al}$ & $\mathrm{Hf}$ & $\mathrm{C}$ & $\mathrm{Ni}$ \\
\hline Content & $2-4$ & $7-10$ & $2-4$ & $6-9$ & $7-9$ & $3-5$ & $2-4$ & $0.5-1.5$ & $5-6$ & $0.1-0.3$ & $0.001-0.01$ & Bal. \\
\hline
\end{tabular}



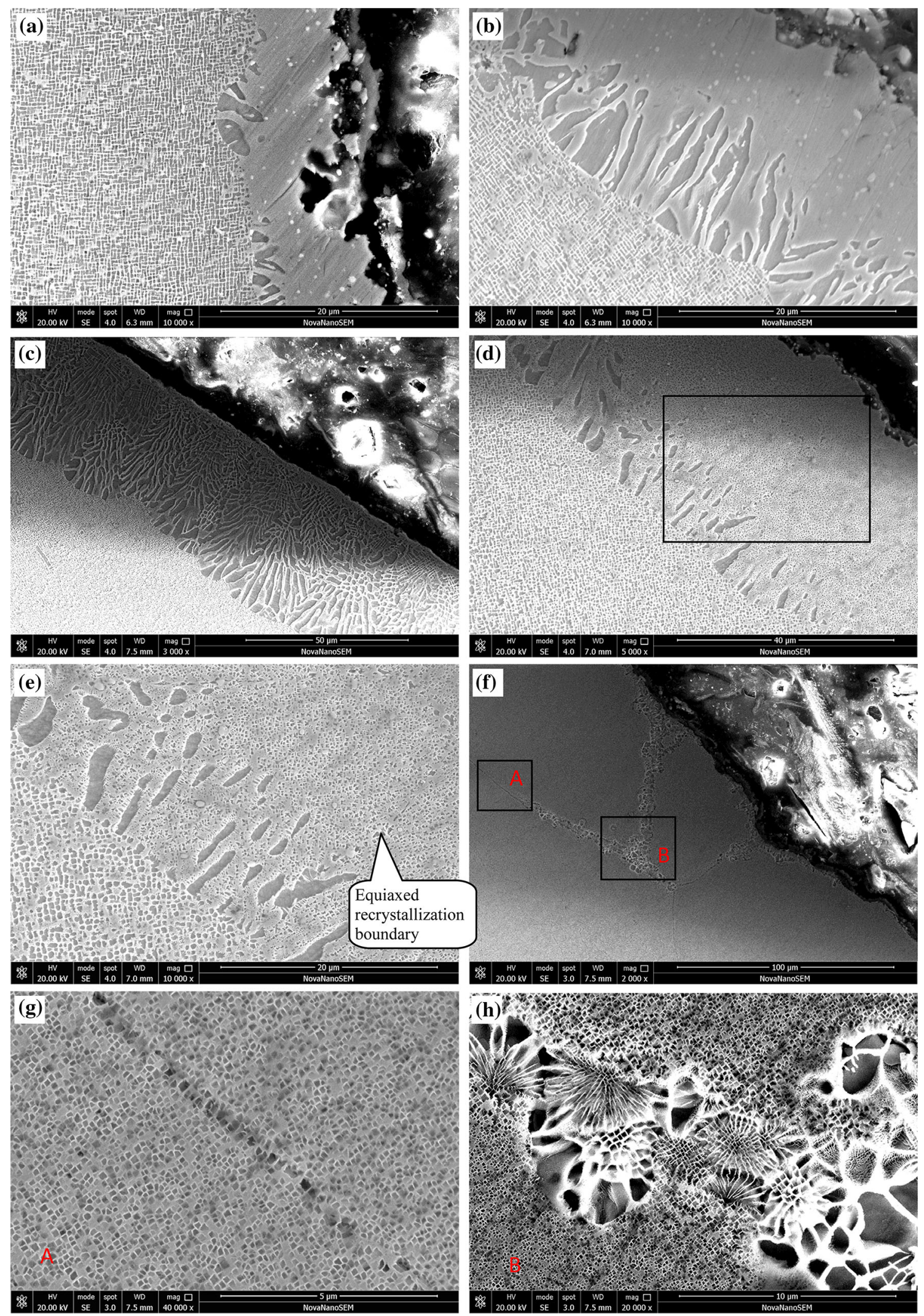

Fig. 2 Surface microstructure of the grit-blasted alloy after heat treatment at different temperatures for 4 h. a $1100{ }^{\circ} \mathrm{C} ; \mathbf{b} 1150{ }^{\circ} \mathrm{C}$; $\mathbf{c} 1200{ }^{\circ} \mathrm{C} ; \mathbf{d}$, e $1250{ }^{\circ} \mathrm{C} ; \mathbf{f}-\mathbf{h} 1300{ }^{\circ} \mathrm{C}$ 
The slightly large and irregular shaped $\gamma^{\prime}$ phase particles precipitated at the equiaxed/recrystallization boundary.

When the specimen was heat-treated at $1300{ }^{\circ} \mathrm{C}$ for $4 \mathrm{~h}$, an equiaxed recrystallization occurred, while the cellular recrystallization was not found (see Fig. 2f). The grain size was clearly larger than that of the specimen heat-treated at $1250{ }^{\circ} \mathrm{C}$. There are two kinds of boundary shapes for the equiaxed recrystallization. One is the narrow grain boundary made up of relatively regular $\gamma^{\prime}$ phase particles (see Fig. 2g). Another is the wider boundary made up of very irregular $\gamma^{\prime}$ phase particles with uniform size, which has been called cellular grain boundary [17], as shown in Fig. $2 h$.

The recrystallized depths after heat treatment at different temperatures are shown in Fig. 3. The recrystallized depth clearly increases with an increase in the heat treatment temperature and exceeds that of the cold-worked zone, except for the specimen heated at $1100{ }^{\circ} \mathrm{C}$.

\subsection{Stress Rupture Properties}

Figure 4 shows the variation of the stress rupture properties at $1150{ }^{\circ} \mathrm{C} / 120 \mathrm{MPa}$ after heat treatment at different temperatures. Each data are the average of three tests. The stress rupture life continuously decreased with a rise of the heat treatment temperature up to $1250^{\circ} \mathrm{C}$. Although the overall stress rupture life reduced to different degrees, the stress rupture life of specimens after heat treatment at $1300{ }^{\circ} \mathrm{C}$ was relatively high and between those of specimens heated at 1150 and $1200{ }^{\circ} \mathrm{C}$. This result is different from those reported by Xiong et al. [9]. However, with a rise of the heat treatment temperature, the trend of elongation was relatively complex. The elongation decreased to different degrees with an increase in temperature and reached a minimum after the specimen was heat-treated at $1300{ }^{\circ} \mathrm{C}$.

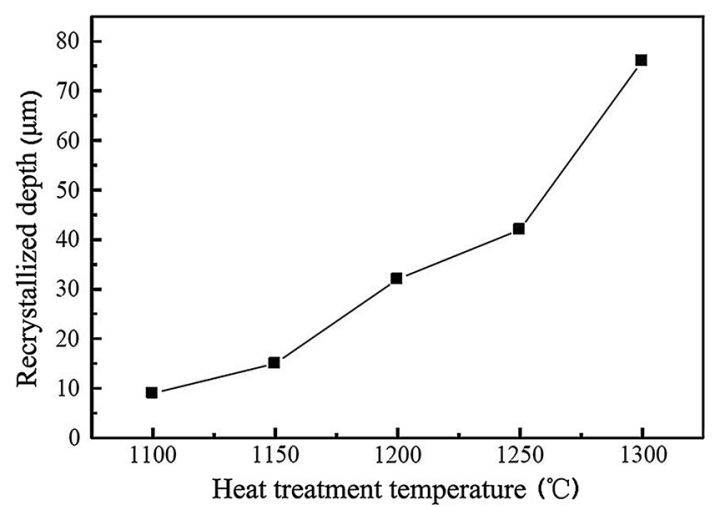

Fig. 3 Recrystallized depth after heat treatment at different temperatures

\section{Discussion}

\subsection{Surface Recrystallization Behavior}

Grit blasting at room temperature resulted in a distorted $\gamma^{\prime}$ phase and a plastic deformation at the specimen surface [9]. There was an extensive concentration of retained energy in the cold-worked zone [12]. Then, surface recrystallization took place during the subsequent heat treatment at high temperature. The recrystallization form and the depth of the recrystallized layer were determined by the heat treatment temperature under the same condition of grit blasting. The deformation temperature had an important influence on the recrystallization behavior $[18,19]$.

A cellular recrystallization occurred in the surface layer after heating at 1100,1150 and $1200{ }^{\circ} \mathrm{C}$ for $4 \mathrm{~h}$. An equiaxed recrystallization formed as the specimens were heat-treated at $1300{ }^{\circ} \mathrm{C}$ for $4 \mathrm{~h}$. Conversely, the coexistence of equiaxed recrystallization grains and cellular recrystallization, defined as mixed recrystallization, occurred in specimens heat-treated at $1250{ }^{\circ} \mathrm{C}$ for $4 \mathrm{~h}$. The single-crystal superalloy was mainly made up of $\gamma^{\prime}$ phase and $\gamma$ matrix, while the $\gamma^{\prime}$ phase had a strong inhibition on the recrystallization [19]. Wei Ping indicated that the $\gamma^{\prime}$ phase dissolution is an important condition for the grain recrystallization [20]. So, it is very important to analyze the conditions for the $\gamma^{\prime}$ phase dissolution produced by the different heat treatment processes.

Figure 5 illustrates the internal microstructure of the alloy after heat treatment at different temperatures. The size of the $\gamma^{\prime}$ phase particles was mainly increased after treatment at 1100 and $1150{ }^{\circ} \mathrm{C}$ for $4 \mathrm{~h}$. In addition, some particles dissolved after heating at $1200{ }^{\circ} \mathrm{C}$ for $4 \mathrm{~h}$. The volume fraction of the $\gamma^{\prime}$ phase dissolved increased significantly when heating at $1250{ }^{\circ} \mathrm{C}$ for $4 \mathrm{~h}$. All the $\gamma^{\prime}$ phase dissolved completely by heat treatment at $1300{ }^{\circ} \mathrm{C}$ for $4 \mathrm{~h}$. The $\gamma^{\prime}$ phase dissolved at different temperatures would precipitate again during the subsequent cooling process.

When the specimen was heated at 1100 and $1150{ }^{\circ} \mathrm{C}$, the distorted $\gamma^{\prime}$ phase dissolved into the $\gamma$ matrix because of the existence of residual stress, although the temperature was below that for the $\gamma^{\prime}$ phase dissolution. It has been reported that residual stress assists the dissolution of the existing phase [21]. The $\gamma$ matrix soon reached saturation, which was a very unstable state. The coarse cellular $\gamma^{\prime}$ phase particles tend to precipitate again to make the system stable [22]. This process is known as cellular recrystallization. The fact that some of $\gamma^{\prime}$ phase particles dissolved when heated at $1200{ }^{\circ} \mathrm{C}$ made the cellular recrystallization more perfect and deeper because the recrystallization resistance decreased. The recrystallization resistance was 

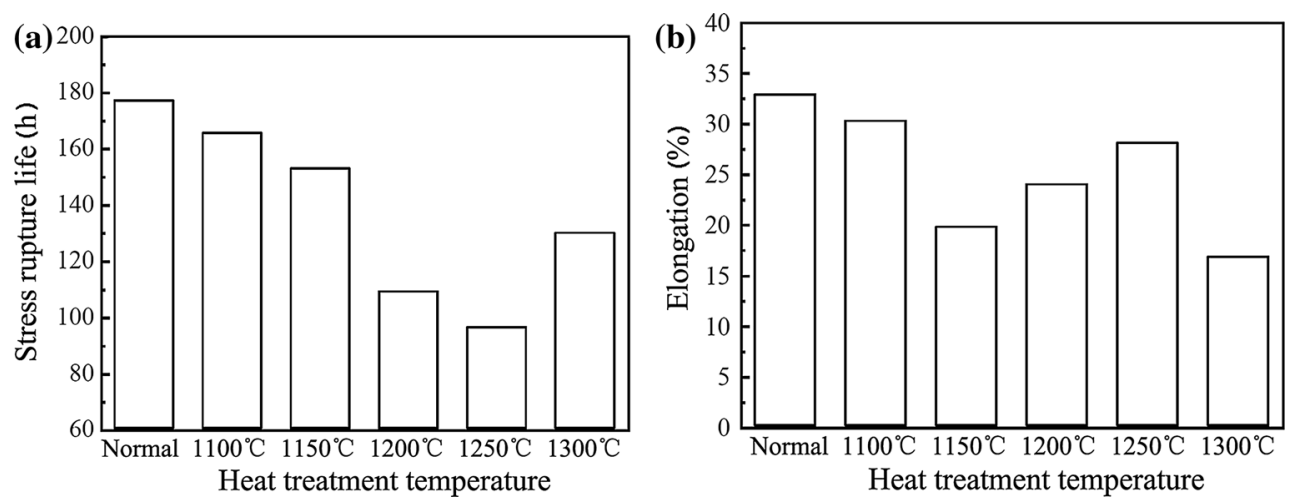

Fig. 4 Stress rupture properties of the alloy at $1150{ }^{\circ} \mathrm{C} / 120 \mathrm{MPa}$ after heat treatment at different temperatures: a stress rupture life; $\mathbf{b}$ elongation

greatly reduced and the equiaxed recrystallization formed because all the $\gamma^{\prime}$ phase dissolved completely after being heated at $1300{ }^{\circ} \mathrm{C}$ for $4 \mathrm{~h}$. Conversely, part of $\gamma^{\prime}$ phase dissolution resulted in the formation of mixed recrystallization in the specimen heat-treated at $1250{ }^{\circ} \mathrm{C}$ for $4 \mathrm{~h}$.

The recrystallization nucleation and growth are related to the heat treatment temperature through an Arrheniustype equation [23].

$D=D_{0} \exp (-Q / R T)$,

where $D$ is the nucleation rate or the grain growth rate, $D_{0}$ is a constant, $R$ the gas constant, $Q$ the activation energy and $T$ the absolute temperature. So, with a rise of the heat treatment temperature, the nucleation rate and the grain growth rate all increase and the depth of the recrystallized layer will increase, as shown in Fig. 3.

\subsection{Stress Rupture Properties Change}

The experimental alloy contains small amounts of grain boundary strengthening elements, such as $\mathrm{Hf}$ and $\mathrm{C}$, in order to enhance the incipient melting point. After the recrystallization occurred, the recrystallized grain boundaries become the weakest regions of the strength and are detrimental to the mechanical properties of the alloy [13, 19]. The cracks initiated and propagated at the grain boundaries perpendicular to the stress axis in the deformation process result from the lower strength of the recrystallized layer and the inhomogeneous deformation between the recrystallized layer and the matrix [5].

The recrystallized layer had almost no bearing capacity, so that the actual stress acting on the matrix increased, which is one of the reasons for the decrease in the stress rupture life. When the depth of the recrystallized layer increases, the recrystallized fraction of the transverse section increases and thus the actual stress acting on the matrix is enhanced. So, the stress rupture life of the alloy tends to decrease with an increase in the recrystallized depth. However, the stress rupture life is not only related to the sample surface recrystallization, but is also related to the internal microstructure of the sample. Therefore, also the specimen internal strength has much effect on the stress rupture life of the alloy.

The nickel-based single-crystal superalloys are mainly strengthened by the $\gamma^{\prime}$ phase. So, the stress rupture properties depend on the morphology, size, volume fraction and distribution of the $\gamma^{\prime}$ phase. It has been reported that the $\gamma^{\prime}$ coarsening is responsible for the degradation of the stress rupture properties of single-crystal superalloys [24]. The size of the $\gamma^{\prime}$ particles became much larger and less uniform with a rise of the heating temperature, especially at 1200 and $1250{ }^{\circ} \mathrm{C}$, as shown in Fig. 5d, e. The $\gamma / \gamma^{\prime}$ interface is an obstacle for the dislocation movement. So, the $\gamma / \gamma^{\prime}$ interface plays a major role in the development of strength and creep resistance: for this it is always desirable to have fine, uniform and coherent cubic-shaped precipitates throughout the whole microstructure. The dense $\gamma / \gamma^{\prime}$ interfacial dislocation network effectively prevents the dislocations from cutting into the $\gamma^{\prime}$ phase [25]. Therefore, with an increase in the size of the $\gamma^{\prime}$ particles and a decrease in the volume fraction, the strengthening effect decreases. This is the second reason for the great decrease in the stress rupture life of the alloy when heated at 1200 and $1250{ }^{\circ} \mathrm{C}$. However, the small $\gamma^{\prime}$ phase precipitated again and underwent a complete solution after heat treatment at $1300{ }^{\circ} \mathrm{C}$ for $4 \mathrm{~h}$ (Fig. 5f). The volume fraction of the $\gamma^{\prime}$ phase increased accordingly. So, the stress rupture life of specimens after heating at $1300{ }^{\circ} \mathrm{C}$ was relatively longer than that of specimens heat-treated at 1200 or $1250{ }^{\circ} \mathrm{C}$, although an equiaxed recrystallization occurred in the surface layer. 

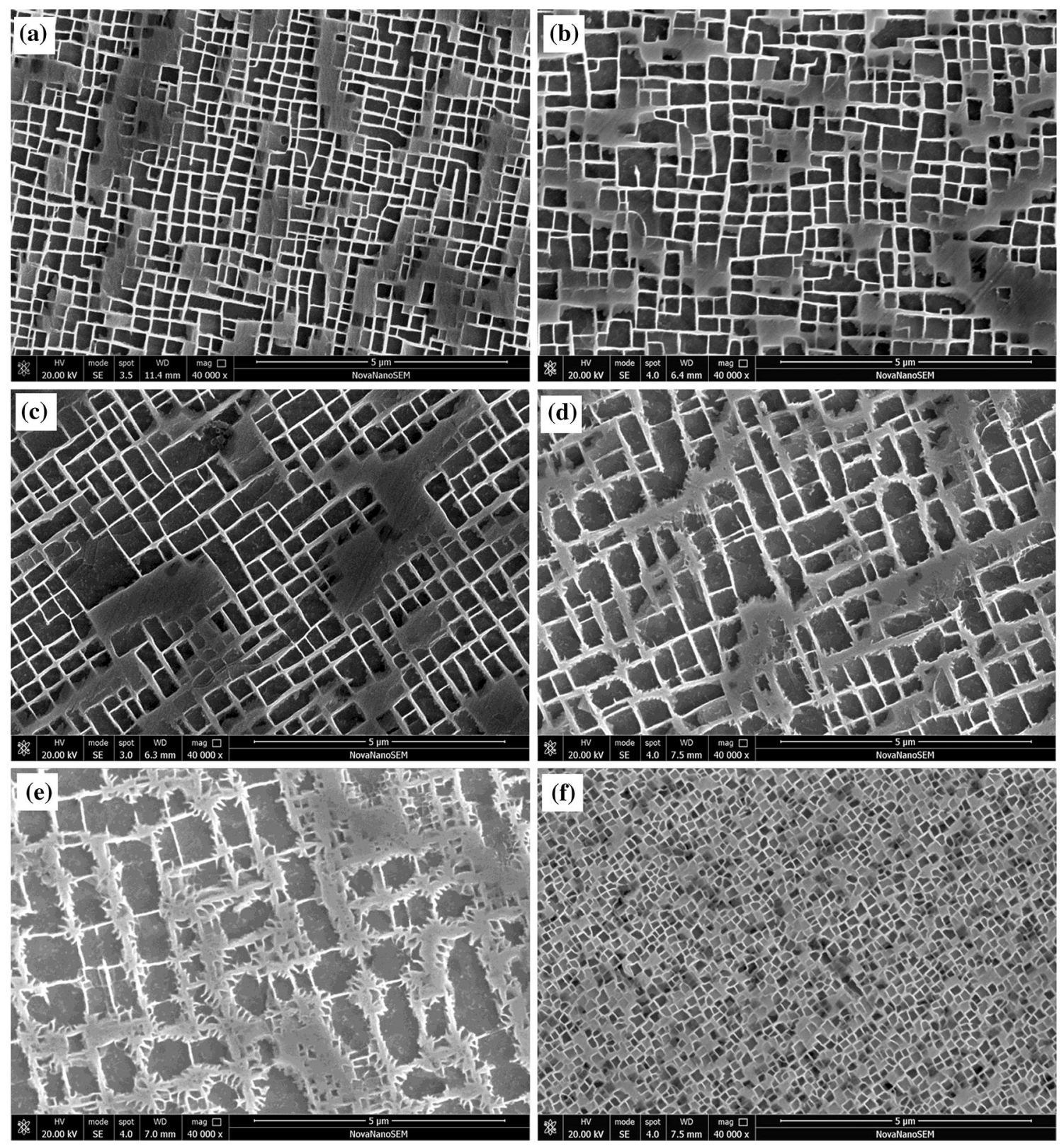

Fig. 5 Internal microstructure of the grit-blasted alloy after heat treatment at different temperatures for 4 h: a normal; b $1100{ }^{\circ} \mathrm{C}$; c $1150{ }^{\circ} \mathrm{C}$; d $1200{ }^{\circ} \mathrm{C} ;$ e $1250{ }^{\circ} \mathrm{C} ; \mathbf{f} 1300{ }^{\circ} \mathrm{C}$

\section{Conclusions}

1. A cellular recrystallization occurred in the surface layer after heating at 1100,1150 and $1200{ }^{\circ} \mathrm{C}$ for $4 \mathrm{~h}$. An equiaxed recrystallization developed as the specimens were heat-treated at $1300{ }^{\circ} \mathrm{C}$ for $4 \mathrm{~h}$. Conversely, a mixed recrystallization occurred in specimens heat-treated at $1250{ }^{\circ} \mathrm{C}$ for $4 \mathrm{~h}$. The recrystallized depth clearly increased with a rise of the heat treatment temperature.

2. The stress rupture life continuously decreased with a rise of the heat treatment temperature up to $1250{ }^{\circ} \mathrm{C}$.
Although the overall stress rupture life reduced to different degrees, the stress rupture life of specimens after heat treatment at $1300{ }^{\circ} \mathrm{C}$ was relatively high and between that of specimens treated at 1150 and $1200{ }^{\circ} \mathrm{C}$.

3. The fact that the stress rupture life was reduced to different degrees after heat treatment can be attributed to the recrystallization of a surface layer and to the microstructure evolution in the interior of the specimens. The small $\gamma^{\prime}$ phase particles precipitate again after heat treatment at $1300{ }^{\circ} \mathrm{C}$ for $4 \mathrm{~h}$. So, the stress rupture life was relatively longer than that of 
specimens heat-treated at 1200 or $1250{ }^{\circ} \mathrm{C}$, although an equiaxed recrystallization occurred in the surface layer.

\section{References}

[1] D. Rgence, C. Vernault, Y. Desvallees, D. Fournier, in Superalloys, ed. by T.M. Pollock, R.D. Kissinger, R.R. Bowman, K.A. Green, M. Mclean, S. Olson, J.J. Schirra (TMS, Warrendale, 2000), p. 829

[2] S. Walston, A. Cetel, R. Mackay, K.O. Hara, D. Duhl, R. Dreshfield, in Superalloys, ed. by K.A. Green, T.M. Pollock, H. Harada, T.W. Howson, R.C. Reed, J.J. Schirra, S. Walston (TMS, Pennsylvania, 2004), p. 15

[3] P. Caron, T. Khan, Aerosp. Sci. Technol. 3, 513 (1999)

[4] L.H. Rettberg, T.M. Pollock, Acta Mater. 73, 287 (2014)

[5] B. Zhang, X. Lu, D.L. Liu, C.H. Tao, Mater. Sci. Eng. A 551, 149 (2012)

[6] Z.L. Li, J.C. Xiong, Q.Y. Xu, J.R. Li, B.C. Liu, J. Mater. Process. Technol. 217, 1 (2015)

[7] Z.L. Li, Q.Y. Xu, B.C. Liu, Comput. Mater. Sci. 107, 122 (2015)

[8] J.C. Xiong, J.R. Li, S.Z. Liu, Mater. Charact. 23, 478 (2010)

[9] J.C. Xiong, J.R. Li, F.L. Sun, S.Z. Liu, M. Han, Acta Metall. Sin. 50(6), 737 (2014). (in Chinese)
[10] C. Zambaldi, F. Roters, D. Raabe, U. Glatzel, Mater. Sci. Eng. A 454-455, 433 (2007)

[11] D.C. Cox, B. Roebuck, C.M. Rae, R.C. Reed, Mater. Sci. Technol. 19, 440 (2003)

[12] W.J. Wei, H.J. Tang, Q. Feng, Mater. Eng. (8), 42 (2011). (in Chinese)

[13] Y.H. He, X.Q. Hou, C.H. Tao, F.K. Han, Eng. Fail. Anal. 18, 944 (2011)

[14] J. Meng, T. Jin, X.F. Sun, Z.Q. Hu, Mater. Sci. Eng. A 527, 6119 (2010)

[15] X. Ma, H.J. Shi, J. Gu, Z. Yang, G. Chen, O. Luesebrink, H. Harders, Fatigue Fract. Eng. Mater. Struct. 38, 340 (2015)

[16] J. Meng, T. Jin, X.F. Sun, Z.Q. Hu, Int. J. Miner. Metall. Mater. 18(2), 197 (2011)

[17] Y.P. Qu, L.R. Liu, G.Q. Zhu, T. Jin, Z.Q. Hu, Mater. Eng. (3), 14 (2011). (in Chinese)

[18] Z.L. Li, X.Y. Fan, Q.Y. Xu, B.C. Liu, Mater. Lett. 160, 318 (2015)

[19] Z.L. Li, Q.Y. Xu, B.C. Liu, J. Alloys Compd. 672, 457 (2016)

[20] P. Wei, J.R. Li, Z.G. Zhong, Mater. Eng. (10), 5 (2001). (in Chinese)

[21] C.Y. Jo, H.Y. Cho, H.M. Kim, Mater. Sci. Technol. 19(12), $1671(2003)$

[22] A. Porter, B.J. Ralph, Mater. Sci. 16(3), 707 (1981)

[23] D. Feng, Metal Physics (Publishing Company of Science and Technology, Beijing, 1998), p. 492

[24] M.V. Acharya, G.E. Fuchs, Mater. Sci. Eng. A 381, 143 (2004)

[25] J.X. Zhang, J.C. Wang, H. Harada, Acta Mater. 53, 4623 (2005) 